\title{
Improving the Interpersonal Intelligence of the Students with Intellectual Disability through the BCCT Approach
}

\author{
Yuana Maulidia, Sopingi, Usep Kustiawan \\ Universitas Negeri Malang, Indonesia \\ Email: yuanamaulidia@gmail.com
}

\begin{abstract}
Children with intellectual disability have a slow social development. Such as the interpersonal aspects of intelligence. The learning approach that can be used is Beyond Centers And Circle Time (BCCT) approach. The purpose is to describe interpersonal intelligence before and after being given the treatment as well as analyze the effect of the approach Beyond Centers And Circle Time approach interpersonal intelligence intellectual disability. The method used was Quasi-Experiment with Time Series Design and analysis with Wilcoxon test hypothesis. Based on the data analysis, It can be concluded that the BCCT approach effect significantly for the interpersonal intelligence of the students with intellectual disability. Keywords: interpersonal intelligence, BCCT, intellectual disability.
\end{abstract}

\section{INTRODUCTION}

Special education arranged in UU No 2 Tahun 2003 about National Education System Article 32 mentioned that "Special education is Education for children who had grade difficulties in following learning process because of emotional mental, and social disorders.

One of the special need children is children with Intellectual disability that children had under average intellectual difficulties. Children who have mental retardation like intellectual disability, they also have a slow social development like Oktaria (2014), children with the intellectual disability did not know how to start social interaction with others. Children with intellectual disability are difficult to have the friendship, it is because children with intellectual disability often show abnormal behavior to their friends, that makes their friend like a distance and do not want to make a friendship with children intellectual disability (Mangunsong, 2009).

Based on the observation result in SLB Idayu 1 Malang in 4th-grade class, there are 2 children with an intellectual disability KLA and RZL, in psychology test, KLA is a child that has low confident, then RZL is still can socialize but RZL cannot understand the intention and feeling of others, in that time KLA just wanted to play with RZL, KLA never socialize with another friend. In that time I gave a class which is the group and KLA started to say although just a little, it showed that KLA and must followed up to the group class. The problem of the child is the low level of personal intelligence in children with intellectual disability in one class that have 6 students, 4 girls, and 2 boys, showed a lot of characteristic on that 6 students when the class starts there are 2 girls with initial KLA and SLS, who are very passive and never did a communication with their friend, they just wanted to play with one friend only. Then SF who often did a conversation with her self, her concentrate is easily disturbed when the lesson takes a place, SS had a less empathy skill that showed when her friend feels difficult to reach her book when the book falls in near her. SS just keep quiescent and that respond. There is a boy with initial RZL when the lesson had started, he talked too much, noisy, low empathy skill, and KK is a boy student who had wood that not always good, he just helped his closest friend who he enjoyed the most another thing that affects interpersonal intelligence children with intellectual disability in one class that not well developed is lack of teacher teaching variation, monotone learning that caused children with intellectual disability easily Borel, and lack of teacher's teaching style.

Observation result teacher used discourse and writing method, teacher opinion is children who have under average of intellectual intelligence is human who must get a lessons about reading and writing, copywriting, children just give exercise to did in home give a lot of easiness, and prosperity that is much for children who has under average intellectual intelligence when doing, a tas and make children's not developing another intelligence that must he developing since early stage as a stock for children when they are in social environment in society, so that children can adaptation in social environment, based on this condition researcher wanted to focus on one of the children multiple intelligence with increasing interpersonal 
intelligent children with intellectual disability.

Anisyah \& Anisyah (2017) said that 9 multiple intelligences of human are (1) Verbal-linguistic intelligence, (2) Logical intelligence, (3) Visual special intelligence, (4) Body and movement intelligence, (5) Intrapersonal intelligence, (6) Interpersonal intelligence, (7) Rhtym musical intelligence, (8) Natural intelligence, (9) Spiritual intelligence (Jamaris, 2017).

One of the most important intelligence to be developed is interpersonal intelligence emphasizing the interpersonal aspect of intelligence because interpersonal or interpersonal intelligence is important to support social life among individuals. This interpersonal intelligence encompasses many social aspects such as emotion, the ability to empathize, the ability to respond appropriately to the mood, motivation, and desire of others. From this opinion, the importance of interpersonal intelligence is developed in the learner, because if the learner has a brilliant academic achievement, if the learner is not able to manage the interpersonal or interpersonal intelligence, the achievement is not much use in the learners themselves (Uno \& Kuadrat, 2009).

This interpersonal intelligence allows us to approach others, and understand them through facial expressions, gestures, and sounds. Someone whose interpersonal intelligence is well developed can talk, and discuss with others effectively (Sanan et al., 2018).

Interpersonal intelligence needs to be developed as early as possible for the needs of subsequent human life because having good interpersonal intelligence children will more easily live their lives. The curriculum that can develop interpersonal intelligence includes group learning, working on a project and making friends in social life. Interpersonal intelligence can also be developed using group learning approaches (cooperative learning) (Sujiono et al., 2010).

Given the interpersonal intelligence is a very important part of everyday life it should be instilled as early as possible. Interpersonal intelligence can be developed through a variety of approaches, one of which is the Beyond Centers and Circle Time (BCCT) approach that is the concept of learning where the teacher presents the real world into the classroom and connects the knowledge of the child with his daily life (Nurmalasari, 2013).

This BCCT approach has been developed based on 25 years of theoretical study by the 25 -yearold Creative Center for Childhood Research and Training (CCRT) for normal children or for children with special needs (Kunarti, 2008). The BCCT approach is realized based on the concepts and theories of experts that have been tested. Beyond Centers And Circle Time (BCCT) is a child- focused approach where the learning process is centered in the center and when the child is in a circle (Asmawati, 2015).

Kirk et al. (2009) says to develop and train children with intellectual barriers of intelligence by providing teaching like role-playing and learning that trains children to interact with people. One approach that provides play-based role-based social interaction is the BCCT approach.

In the BCCT approach is more popular with the term SELING (centers and circles) is an approach designed in the form of centers. Play activities provide a great opportunity for the child to develop the experience and knowledge that the child has through interaction with his peers.

Centers are applied to bring children to experience exploring and interacting with others around them. This center learning model is divided into several centers, such as the central role, music center, beam center, worship, creativity center and science center. Lessons using the center approach have many benefits for improving children's social development as revealed by some educational experts' views that, "believing that children who are learning with center-based learning through direct interaction with other children will make social intelligence or interpersonal intelligence will thrive (Asmawati, 2015).

Based on limited and skills that younger children's have for a study about concrete things and real facts in daily life, this things is along with research by Nurmalasari (2013) that BCCT approach can increase social skill children with intellectual disability. The result by Safaria (2005) research showed that PAUD inclusive Ahsanu Amala Yogyakarta used BCCT learning approach for increasing socialize skill and in creator between special need regular children in PAUD inclusion.

Based on the explanation that has been put forward researches did a research about The Effect of Beyond Centers and Circle Time towards Interpersonal Intelligence of the student with intellectual disability of the student with intellectual disability in 4th grade.

\section{METHOD}

The method used in this research is QuasiExperimental Design with Time series design. The subject in this research is children with intellectual disability in 4th-grade SLB Idayu 1 Malang even semester school year 2017 2018 that have 6 students, 4 girls 2 boys. In this research is using observation paper, an instrument is a tool for collecting data with for measure interpersonal intelligence children, interpersonal intelligence aspects is made to be bullet point statement. 


\section{Diagram 1. Diagram of result score pretest and} posttest.

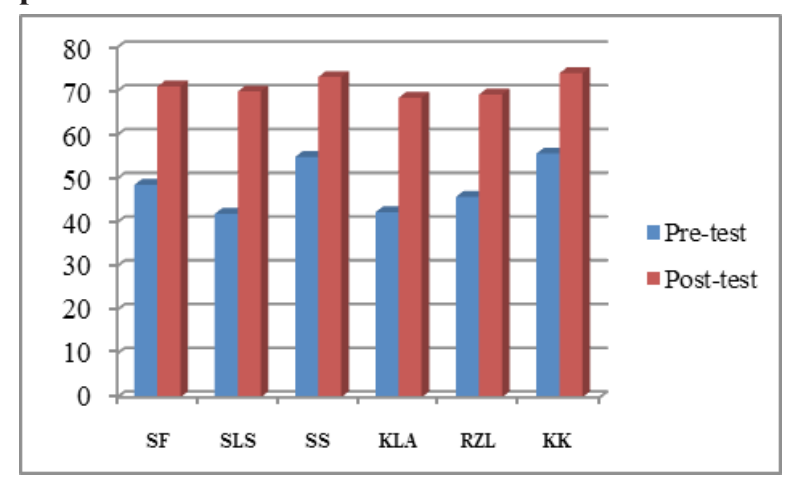

\section{FINDINGS AND DISCUSSION}

\section{Findings}

Based on average score result of pretest before giving a treatment while study and break time SF mean score is 48,26 , SLS mean score is 42 , SS mean score is 55 , KLA mean score 42,37, RZL mean score is 45,87, KK mean score is 55,75 . Based on observation result have gotten data of interpersonal intelligence, they not yet reached assessment criteria of interpersonal intelligence or can be interpreted that children with intellectual disability interpersonal intelligence is still low.

After research he did pretest, students gave a times treatment in successive periods after gave treatment with BCCT learning approach, students have given 4-time periods of posttest, for posttest researcher increase the material of lessons that have been given to student the aim is increasing again for students can understand not memorize the material. In posttest, time researcher is more push it to group studies so the student can show their interpersonal intelligence.

Based on the mean score of posttest interpersonal intelligence after fiving treatment while study and break the student name SF has to mean score 71,09, SLS has to mean score 69,96 , SS has to mean score 73,25 , KLA has to mean score 68,5 , RZL has to mean score 69,25 , and $\mathrm{KK}$ has to mean score 74,12. After correction data of interpersonal intelligence that entered in the criteria on interpersonal intelligence, and the result is better than before treatment with BCCT approach I this bellow is the diagram of recapitulation of pretest and posttest result.

Recapitulation of results score of pretest and posttest in diagram 1. Hypothesis testing in this researcher is using Wilcoxon testing. Wilcoxon testing is a test that notice of different sign positive and negative that determine the real differences between pair data that take from the sample (Hasan, 2009).
Based on comparison result while learning time towards absolute score amount, that taken (smallest) Tcount $=0$ while Table score with $(\alpha 0,05$ and $n=6)$ $=2$. From testing criteria that have been set, so work hypothesis is accepted T-count $<$ Table its mean that $\mathrm{T} 0=0<$ Table $=2$ or $0<2$ its mean H0 decline and Ha accepted.

The conclusion from the result above is hypothesis is accepted, it means that there is a significant difference of using BCCT approach towards interpersonal intelligence children with intellectual disability in 4th grade of SLB Idayu 1 Malang.

\section{Discussion}

There are 9 multiple intelligence according to Anisyah \& Anisyah (2017) there are (1) Verballinguistic intelligence, (2) Logical intelligence, (3) Visual special intelligence, (4) Body and movement intelligence, (5) Intrapersonal intelligence, (6) Interpersonal intelligence, (7) Rhtym musical intelligence, (8) Natural intelligence, (9) Spiritual intelligence (Jamaris, 2017). One of multiple intelligence is very important for developing is interpersonal intelligence which is disclosed by Goleman he said that give push to interpersonal intelligence aspect of interpersonal intelligence is one of intelligence that support our there are 3 dimensions of students interpersonal intelligence that disclose, there are (1) Social Security, (2) Social Insight, and (3) Social Communication (Safaria, 2005).

Based on students while learning times and break times, it showed that socialize and communication between students is low. There is 6 student in class while learning times. One student and others have different interpersonal intelligence for example while giving group task and student and others student keep quiet and did the task by them self, there is one student that wanted to befriend or group just with their closest friend but with other was still keep quiet. This fact is parallel with opinion, children with intellectual disability in their friendship can't take care, maintain and lead of them self. They also cant show the proudness (Restanti \& Chandra, 2017)

In this case, the researcher also observes interpersonal intelligence while break time interpersonal intelligence showed while there are 2 students that played than one student one to join them but 2 students decline him while eating the lunch. There is one of them who didn't bring the lunch but the student didn't want to share his lunch with other friends, another student also has less communication with other friends while break time. Children with intellectual disability have a lack of their interaction 
with the social environment. Children with intellectual disability are less a the empathy and cant interpret others feeling (Hanurawa, 2016).

From this thing, we can see from students protest score while learning a process and while break time before gives treatment. Based on pretest score student get under 60. Learning model that using centers to bring children to exploration with others in around BCCT approach is often called SELING on centers and while on the circle. Centers means the center of learning that designed with playtime to increase all potential children (Ismail, 2016).

While BCCT learning time all 6 student looks that they are like the process of learning based on centers and circle. They are no more again selecting a friend, start interacting with other friends, empathy behavior appeared while learning time. Before giving treatment, the never study in the group like BCCT approach, while giving treatment using BCCT approach students are very enthusiast because they can be learning while playing. After 4 seasons learning using the BCCT approach look at the differences in children behavior to their friend, like they never selected friend, student after play together. After giving treatment, the student can clean their toys by themselves because students are used with BCCT method while learning process students must clean their toys by them self. Students have the initiative to role play with their friends like when role play center treatment. In this case, it proves that the more children play together, the more children learn to interact and understand others. According to Sujiono et al. (2010) said that the technique of developing interpersonal intelligence of children one of them is developing group support (Sujiono et al., 2010).

When giving posttest, researcher give may group task learning, they seem very happy and a lot of interaction with their friend they also didn't selecting sit place like before giving treatment. This is line with opinion that to sharpen children interpersonal skill teacher should pushing children to a workgroup, help children to develop their communication skill and provide them with a game of group for children activity (Santrock, 2014).

BCCT of Sentra of learning is an approach that put a real world to the class and connecting children's knowledge with daily live, BCCT approach can maximalize all of the children intelligence like what (Anjaryati, 2011) said that BCCT approach is for stimulating all aspect of intelligence through learning activity while playing centers or footing setting.

When implementing BCCT approach in each center's students always doing communication with their friend or children student must use all of their intelligence to study or play before doing the implementation of BCCT student are less communication with others with BCCT students learn to communicate and make a friend. Its line with experts opinion Pestalozzi said that centers have a direct connection while children study through direct interaction with other children. BCCT learning approach is the focus to children and teacher as facilitator in every process. He ached while BCCT learning is giving a support in the form of positive statement and giving questions to children based on their development at once, that also brings up children intelligence in problem-solving (Asmawati, 2015).

BCCT is a learning approach based on centers and gives a scaffolding so that children can bring up their interpersonal intelligence in the problemsolving aspect. This statement is in line with opinion they are this scaffolding is given for guiding children and demanding children to be responsible and having better social interaction (Amalia et al., 2015).

BCCT approach give a chance for children to active while having interaction between teacher and students, the student with teacher or student with a student. The result of Nurmalasari (2013) research BCCT approach is an interesting learning approach for children because this approach is using centers that match with children with intellectual disability, characteristics that bored easily and this approach give a chance to interaction, communication and socialize skill while studying.

This result of Machmudah (2011) research with title Sentra and circle learning method for developing interpersonal intelligence of children in playgroup Restu 2 Malang is interpersonal intelligence not just using role paying center of some Sentra in BCCT can be implemented to children for increasing their interpersonal intelligence.

\section{CONCLUSION}

Based on analysis to the result of this research that has been, we got the conclusion on that: the Interpersonal intelligence of children with an intellectual disability before giving treatments and after giving treatments and when playtime is increasing. It means that interpersonal intelligence as well increasing the result of table calculation of Wilcoxon test table got Tcount $<$ Table. From that result, we can be summed up that there are differences of a positive score between through interpersonal intelligence children with intellectual disability in 4th class SLB Idayu 1 Malang.

BCCT approach can be one of the learning alternative programs taught in school and teachers should develop interpersonal intelligence in easily stage for supporting another intelligence, for next researcher about BCCT approach is to know the effectiveness of BCCT approach. 


\section{REFERENCES}

Amalia, A., Syukri, M., \& Endang, B. (2015). Penerapan Pendekatan Scaffolding Dalam Pengembangan Keterampilan Sosial Anak Usia 5-6 Tahun. Jurnal Pendidikan dan Pembelajaran, 4(3).

Anisyah, N., \& Anisyah, M. P. I. (2017). Pelaksanaan Pembelajaran Sentra Main Peran Dalam Pengembangan Kecerdasan Interpersonal Dan Kecerdasan Linguistik Anak Usia Dini Di Taman Kanak-Kanak Al-Muthmainnah Kota Jambi. Jurnal An-Nahdhah, 10(2).

Anjaryati, F. (2011). Pendidikan Inklusi dalam Pembelajaran Beyond Centers and Circle Times (BCCT) di PAUD Inklusi Ahsanu Amala. Yogyakarta.

Asmawati, L. (2015). Pengelolaan Kegiatan Pengembangan Anak Usia Dini. Tanggerang Selatan: Universitas Terbuka.

Hanurawa, F. (2016). Perspektif Alternatif Dalam Psikologi Pendidikan. Malang: Universitas Negeri Malang.

Hasan, I. (2009). Analisis Data Penelitian Dengan Statistik. Jakarta: Bumi Aksara.

Ismail, I. (2016). Integrasi Pendidikan Karakter Anak Usia Dini Melalui Model Pembelajaran Berbasis Beyond Centers And Circle Time (BCCT). Wahana Akademika: Jurnal Studi Islam dan Sosial, 15(1), 41-60.

Jamaris, M. (2017). Pengukuran Kecerdasan Jamak. Bogor: Ghalia Indonesia.

Kirk, S., Gallagher, J., Coleman, R. M., \& Anastasiow, N. (2009). Educating Exceptional Children. U.S.A: Houghton Miffl in Harcourt Publishing Company

Kunarti. (2008). Penerapan Pendekatan Pembelajaran Beyond Centers And Circle Time (Bcct) Dan Kurikulum Yang Sesuai Dengan Perkembangan Anak/Developmentally Appropriate Practice (Dap). Tesis, Universitas Negeri Padang.

Machmudah, R. A. (2011). Metode Pembelajaran Sentra Dan Lingkaran Dalam Mengembangkan Kecerdasan Interpersonal Anak Kelompok Bermain Restu 2 Malang. SKRIPSI Jurusan Pendidikan Luar Sekolah-Fakultas Ilmu Pendidikan UM.
Mangunsong, F. (2009). Psikologi dan Pendidikan Luar Biasa. Jakarta: Lembaga Pengembangan Sarana Pengukuran dan Pendidikan Psikologi (LPSP3) Universitas Indonesia.

Nurmalasari, D. 2013. Pengaruh Pendekatan Beyond Centers And Circle Time (BCCT) Sentra Bermain Peran Naik Kendaraan Terhadap Peningkatan Keterampilan Sosial Anak Tunagrahita Sedang Di SLB Pancaran Iman. (Doctoral dissertation, Universitas Pendidikan Indonesia).

Oktaria, R. (2014). Evaluasi Program Implementasi Pendekatan Beyond Centers And Circle Time (BCCT). Jurnal Pendidikan Usia Dini, 8(2), 337352.

Restanti, A. D., \& Candra, A. H. (2013). Peningkatan Kemampuan Daya Ingat Anak Tunagrahita Melalui Musik Dalam pembelajaran. Jurnal Ortopedagogia, 1(1), 46.

Safaria, T. (2005). Interpersonal Intelligence Metode Pengembangan Kecerdasan Interpersonal Anak. Yogyakarta: Amara Books.

Santrock, W. J. (2014). Psikologi Pendidikan Educational Psychology. Jakarta: Salemba Humanika.

Sanan, S. M., Hussein, A. A., \& Behbood, M. (2018). Multiple Intelligences-Based Planning of EFL Classes. Advances in Language and Literary Studies, 9(2), 98-103.

Sujiono, N., Yuliani., \& Sujiono, B. (2010). Bermain Kreatif Berbasis Kecerdasan Jamak. Jakarta: Indeks.

Sugiyono. 2012. Metode Penelitian dan Pengembangan (Pendekatan Kuantitatif, Kualitatif dan R\&D). Bandung: Alfabeta.

Undang-undang Republik Indonesia Nomor 20. 2003. Tentang Sistem Pendidikan Nasional. Pasal 32.

Uno, B. H., \& Kuadrat, M. (2009). Mengelola Sebuah Konsep Pembelajaran Berbasis Kecerdasan. Jakarta: Bumi Aksara. 